\title{
MEDIEVAL SOCIALIST ARTEFACTS: ARCHITECTURE AND DISCOURSES OF NATIONAL IDENTITY IN PROVINCIAL POLAND, 1945-1960
}

\begin{abstract}
José M. Faraldo*
Many things allow us to recognize that the Poles have a greater and fuller affinity with the Poznan Land than the Germans, even today. It is interesting, for example, with what confidence Polish architects, in contrast to their German counterparts, incorporate historical and regional characteristics in their designs.
\end{abstract}

Moritz Jaffé '

The Archive of the Town Curator of Monuments in the Polish city Poznan contains material about streets, monuments, Old Town Square, the cathedral, and other valuable constructions there. A folder labeled Nowy Ratusz (New Town Hall) attracted my attention, because I knew nothing about such a building. The folder contained photographs of a large neo-Gothic building. It looked like a typical Prussian public building, similar to hundreds of other postal, school, and government offices throughout the Prussian/German state. But what of this building? Had it been another casualty of the Second World War? The postwar images showed, that although seriously damaged, the building still stood in the ruins of the Old Town Square.

This building no longer stood on the square, but what had been constructed in its place? Another folder [labeled "Waga Miejska" (Town Scale)] provided the solution to the riddle. This folder contained a series of pictures of the construction of the Town Scale, a building I had often seen while walking near the Renaissance-style Town Hall, the pearl of Poznan architecture. The Town Scale, which was constructed in medieval style, was completed only in the early 1960 s, according to the commemorative plaque on one wall (see Figure 1).

The folder, however, contained another photograph showing a slightly different Town Scale with the notation "pre-1890." It appeared that the old Town Scale had been demolished sometime after that date. Thus, there was both an Old Town Scale and a New Town Scale and between them, a New Town Hall. There was, however, no mention of the New Town Hall, which had stood on the square for more than half a century, in any of my town guides. 


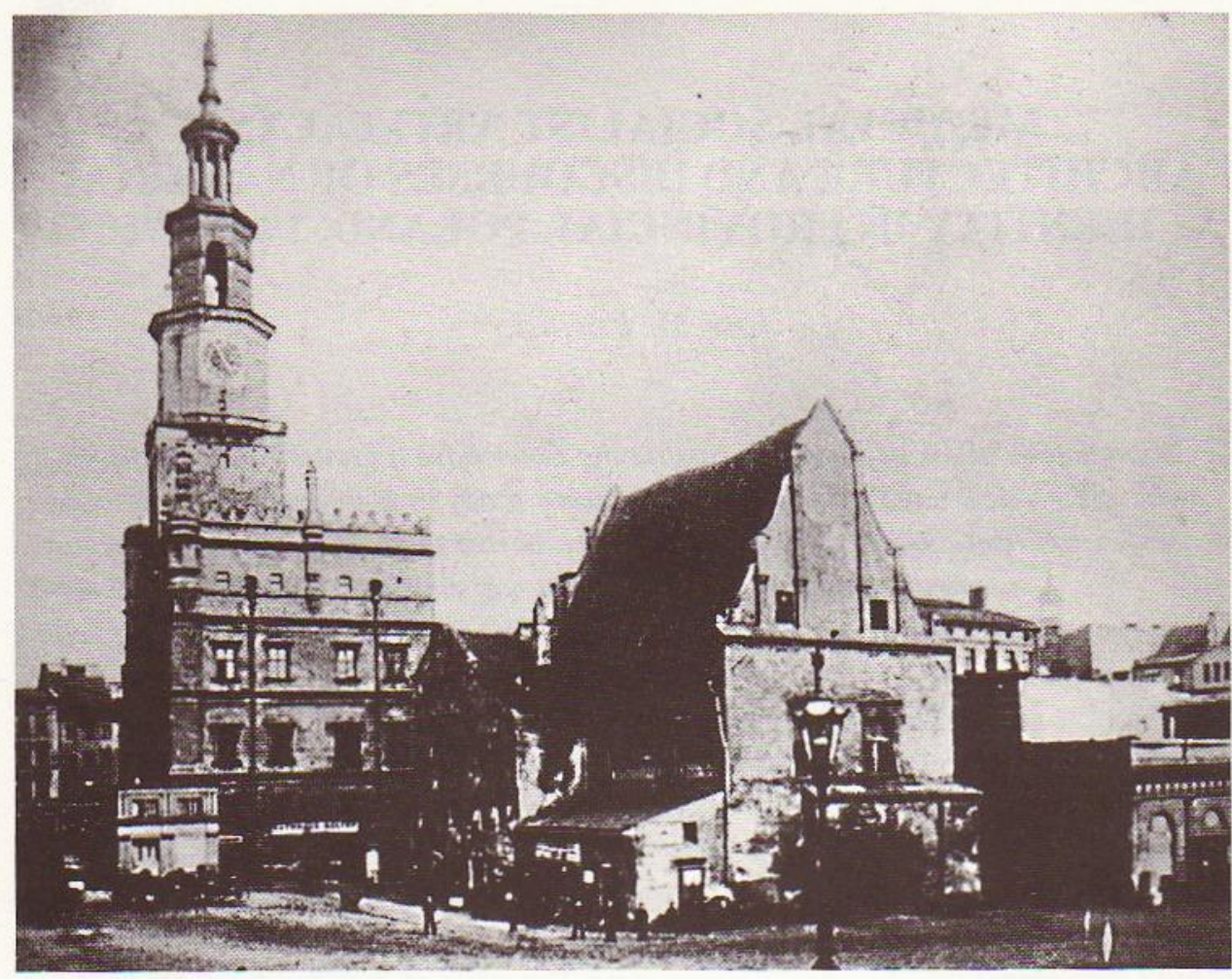

FIGURE 1

Municipal Scale and Old Town Hall around 1890

(Photo: Archiwum Miejskiego Konserwatora Zabytków, Kartoteka, Poznań).

\section{Poznań and the Polish National Myth}

Poznań/Posen is a city in western Poland with a special historical meaning. ${ }^{2}$ The largest city in the Wielkopolska (Greater Poland) region, it is close to Gniezno, the symbolic first capital of the Polish state. In the usual Polish understanding of the history of the country, it is described as an important medieval town, which in the time of the partitions came under Prussian rule but stood like a fortress of Polish national feelings until the final revolt in 1918-1919 and the restoration of independent Poland. ${ }^{3}$ So, if we accept this interpretation, Chancellor Otto von Bismarck's politics of Kulturkampf aimed at germanizing the large Polish population in the former Polish territories. ${ }^{4}$ The residents of Poznan are said to have raised ferocious resistance to these measures. The mythology of this resistance remained alive in the nationalistic element of its Polish inhabitants. This nationalistic activity wrote on the space of city symbols like the monument to Adam Mickiewicz, Poland's national poet, that was put up in $1859 .^{5}$ It is the first Mickiewicz monument in the Polish Lands. 
In fact, not only the Poles left their mark on the landscape. As a representation of his power, the German Kaiser Wilhelm II constructed a new castle, in a sort of neoRomanesque style which tried to represent proof of German dominion over the East. Between 1904 and 1916 a group of buildings (post, banks, Academy, Colonization Office, etc.) was built, which, together with the Kaiser's Castle, formed a new monumental quarter as Poznańs very entrance. For some Poles, the Kaiser's Quarter was an unwelcome sign of Prussian domination and the architecture and style of its components presented an unpleasant view. ${ }^{6}$

After the independence of Poland in 1918, Poznań became an important provincial capital, although the country's main weight lay on its east central side, from Warsaw and \ódż to Cracow, Lwów, and Vilnius. Between the world wars, Poznań was both a fortress of National Democracy - a right-wing Polish movement which evolved into a radical nationalist party - and a town that represented a view toward the West, a bridge between the modern countries of northwestern Europe and the Eastern European states.?

Now a Polish city, interwar Poznań, like much of the rest of the country, still had a significant German and Jewish population. Before 1945, Poland was a multinational state with numerous ethnic minorities and concomitant nationalistic conflicts. ${ }^{8}$

The outbreak of the Second World War in September 1939 brought Poznań again into German hands. Considered originally German by the Nazis, Poznań and its surroundings were annexed to the Reich, and steps were taken to reduce Polish influence and to remodel the town in a German-really a Nazi-manner.' The Nazi planners' conception of a German Posen/Poznan was, judging from the plans and models, a monumental neoclassical town, with attics, columns, and great open spaces, not very different from Albert Speer's designs for Berlin. ${ }^{10}$ However, these plans were finally not executed. Their most important practical consequences were the reorganization of the Kaiser's Castle as an occasional home for Hitler and the expulsion of thousands of Poles into the General Government.

\section{A New Beginning}

Following a month of fighting, Poznań's Citadel was liberated on 23 February 1945, and the last Nazi resistance in the town destroyed, while the Red Army advanced on Berlin. The remaining inhabitants of Poznań could try to get on with their lives, reconstructing their houses and streets, and organizing the local economy after long years of war and occupation. ${ }^{11}$

In a sense, Poznan could be considered a symbolic representation of the whole country as well as a good image for the future Poland. The same processes that were occurring elsewhere in Central Europe also took place in the newly liberated city, like fractals that could be repeated again and again along the chain of magnitude from small village to large state. The bayonets of the Soviet troops bringing a new political order, the new power ruling a country greatly changed by war and its after- 


\section{J. M. FARALDO}

math, ethnic cleansing and large-scale migration, the creation of a new social, economic, and national project, and the reconstruction of the economy and the material buildings themselves were all part of this project. ${ }^{12}$

The political and social tendencies of Europe at that time were directed toward the recovery of democracy in the sense of traditional socialism, maybe because the U.S.S.R. had shown that a communist-ruled country could become a new great power, capable of defeating fascism. The war led to greater state intervention in the economy and reinforced this perception, not only in the countries liberated by the Red Army but also in the United Kingdom and France. Hence, the concept of democracy was bound to both socialism and statism, at least in the immediate postwar period.

The Polish case was no exception. The reorganization of the economy and the material reconstruction of the country were attached to the particular creation of a new view of the national and social future of the nation and to a new rewriting of its history. ${ }^{13}$ The form of such creation was the growing centralization of the whole country in the hands of a formally revolutionary party, which took on itself the duty of modernizing society and the economy.

To modernize the country, even in the peculiar sense that the new Poland's rulers wanted, and because the pre-war Poland failed to become a national state, meant to begin a process of nation building. ${ }^{14}$ During the interwar period, Poland had been a primarily agrarian country, formed of territories from three defunct empires at very different levels of development, inhabited by a variety of ethnic groups, who spoke a babel of languages and had multiple self-identities and attitudes toward the state. In the postwar era, most of the minorities - although not all-were gone and the Soviet model of development seemed, to most communists, the way to overcome backwardness. ${ }^{15}$ The urbanization and industrialization processes could be connected to the shape of a nation, a powerful state-like the U.S.S.R.- that neither could be defeated on the battlefield nor would suffer from nationalities problems as the Second Polish Republic had.

Polish communists' nationalism was more than a rhetoric, a political tactic, ${ }^{16}$ and a contamination of right thinkers. ${ }^{17}$ It was an assumed correction of the errors of the interwar period (when the Polish Communist Party failed to manage Polish nationalism) and a resultant of the ethnification of wartime. ${ }^{18}$ Their nationalism evolved in a context of building a sort of welfare state and of systematic modernization and development of the country. Nevertheless such a welfare state was intended not only as a first step in the shaping of a communist world but also as a means to preserve the communists' power by satisfying people's hopes and demands. The modernization was achieved, however, employing the Stalinist model of rapid industrialization and (partially) the brutal collectivization of agriculture.

Poland's new borders produced a special situation: millions of people from the former eastern Polish lands (kresy) had to move to the new western regions, the former German territories. ${ }^{19}$ The integration of newcomers from diverse parts of the 
old Poland - many without national self-identification, speaking languages other than Polish, with varied habits and traditions-into a modern unified nation was a task that the communist government consciously assumed. ${ }^{20}$ This included a thoroughgoing process of "repolonization" (really polonization) of the remaining Germanness (the so-called "autochtons") ${ }^{21}$ of the Lemkos, and the Ukrainians ${ }^{22}$ and also the Slovaks in Spisz and Orawa. ${ }^{23}$ The process of polonization was well planned and systematically executed. ${ }^{24}$ Schools, the mass media, and even the Roman Catholic Church $^{25}$ were consciously used to achieve this objective. The new rulers stressed the forming of a jednolity Polski naród (homogeneous Polish people). Although the means to achieve this were not the same and its effects were diverse, the Gesamtkunstwerk of the new nation was performed in the whole territory of the new state by old inhabitants, new settlers, minorities and re-emigrants. ${ }^{26}$

This complex process caused the rulers to create a new and specific national selfimage. In constructing an image of the new nation, they had the choice of incorporating cultural traditions that could fit into their project or of shaping a completely new corpus of images. A peculiar mix of both possibilities was developed along the way of reconstructing the country.

\section{Reconstruction as Mythology}

Odbudowa (reconstruction) assumed a special meaning in postwar Poland. ${ }^{27}$ All the states that suffered large-scale material damages during the war had "reconstruction" periods, which came into the history books with a more or less heroic and epic flavor. ${ }^{28}$ But in Poland, the concept of odbudowa had particularly great significance due to the country's peculiarities and the form that Nazi occupation had taken. The Nazis had attacked Polish society both in a traditional military sense and in a way that undermined Polish cultural integrity and national self-image.

During the second half of the nineteenth and the beginning of the twentieth century an element of the Prussian, then German, academic community-historians, economists, and geographers-had practiced intellectual aggression against the Slavic inhabitants of their state. The rise of a new nationalism founded on allegedly scientific racist theories was united with the new homogenization trend of Prussia on the way to becoming a national state. This culminated in the Nazi designation of Slavs as Untermenschen ${ }^{29}$ This aggression was disguised as Ostforschung and, in general, it tried to prove that the major cultural achievements in Eastern Europe were produced by Germans or German influence. At best, Ostforschung could be accused of merely exaggerating trends or supposing unacceptable extrapolation of contemporary categories to past times. The worst cases show a half-paranoid model of denigration of the Poles and the attribution of every important material or spiritual accomplishment in Poland to ethnic German values.$^{30}$ In the fields of architecture and the arts, this tendency produced-among other things-the concept of Deutsche Kolonialkunst (German Colonial Art), which supposedly evolved in towns situated in 


\section{J. M. FARALDO}

ethnic or historic Poland but was the work of German colonists. ${ }^{31}$

The terrible consequences of this theoretical concern are well known: Nazi ideology became reality during the Second World War. The Polish intelligentsia was decimated; universities and education in general for Poles were prohibited. The Nazis expelled and resettled large numbers of people, tried to repopulate and to germanize a great part of their former Polish territories, plundered cultural and artistic objects, destroyed symbolically important buildings and monuments and sought to change the landscape into a more German one. ${ }^{32}$

There were a great variety of plans for Poznań, including a total remodeling of the Old Town in the typical Nazi German national style. ${ }^{33}$ Poznań's Oberbürgermeister in 1940 stressed the necessity of transforming the regional Capital Town into a genuine German landscape, instead of its actual stage as a faceless and devastated landscape. ${ }^{34}$

The major symbolic event, however, was the devastation of Warsaw, especially toward the end of the war. Poles perceived the well-planned destruction of the King's Castle, the Old Town, and the cathedral as an attack on Polish identity with the intent to annihilate the Poles' historical existence. ${ }^{35}$

Thus, the conception of odbudowa acquired a double significance: on the one hand, it expressed the postwar imperatives of reconstructing and reorganizing the ruined economy and the materially desolated land..$^{36}$ This process was increasingly connected to communist domination and after 1948 transmuted into a "socialist reconstruction," which adopted the Stalinist model of economic modernization. ${ }^{37}$

Reconstruction also constituted a reaction against the vandalism of the Nazis and their attempt to eliminate representative elements of Polish history and culture..$^{38}$ This nationalist rebuttal assumed the form of an integral rebuilding of the damaged monuments and, more importantly, also of whole residential areas and districts with historical or sentimental value, even if their artistic or architectonic merit was limited.

The resistance to the cited conception of reconstruction had no real effect. ${ }^{39}$ Ksawery Piwocki's and Kazimierz Wyka's articles opposing reconstruction initiated no real discussion. ${ }^{40}$ Other efforts too were unsuccessful. In a paper for the Ministry of Information and Propaganda, the National Curator, Jan Zachwatowicz, a convinced supporter of the official line, addressed three principal possibilities. ${ }^{41}$ The first was resignation: to demolish the ruins and put up completely new buildings, which, in Zachwatowicz's opinion, would be a continuation of the task the Germans had began: the destruction "of everything that supposes a document of the national past." The second was martyrology applied to the city: the field of ruins was to remain as a monument of history and "a memorial of the savagery of German barbarism." The curator opposed this because nature would destroy the ruins, leaving no trace of either the monuments or the German crimes. The last possibility was odbudowa: the "reconstruction" of "all important elements crucial to the silhouette and the atmosphere of streets and squares." It combined sentimental melancholy and 
nostalgia for the well-known buildings, streets, and alleys, with the new mission of the-renovated-Old Town as "a living member of the Capital.".42

Zachwatowicz tried to find a solution to criticism by some experts who branded the reconstruction-in historical form-as fraudulent imitation. ${ }^{43}$ The National Curator found scientific arguments unsatisfactory. He considered the political necessity of keeping the lost "cards of our history" and opposing the German attack on Polish culture more important. He wrote that "in these conditions there is no place for pure conservatory criteria." ${ }^{44}$

As Marta Leśniakowska has noted, the program of reconstruction gave to Polish art and architectural historians a unique chance to shape a new reality. But it also supposed a "pure political act,"connected to the new government's necessity of (re)creating a new nation, a modernized nation that, nevertheless, could maintain a historical legitimization. ${ }^{45}$

So odbudowa came to be not only an economic premise but a requirement of the new national configuration and of the new national self-identity. Initially, this idea presented was chaotic. With the establishment of the socialist-Stalinist-state, the original sentimental and nationalist conception became linked to the rising sociopolitical model in the shape of socialist realism. The recreation of the old Polish architecture-in historical, not in pre-war forms-fitted perfectly the slogan national in form, socialist in content. ${ }^{46}$

\section{The Reconstruction in Poznań}

According to historian Henryk Kondziela, Poznań's former curator, the reconstruction of the town began even before fighting on the streets had finished. ${ }^{47}$ The first works were aimed at preparing the basic conditions for the smooth running of the city after the war and providing the necessities of everyday life. ${ }^{48}$

Today, it is difficult to establish Poznań's real degree of postwar damage. As in Warsaw, the propaganda concerning war reparations and the need for more credit from the government, could be reasons to overstate the reports. A recent analysis, focusing on Warsaw, may inadvertently contribute to proving this view. ${ }^{49}$

However, judging from the figures of damaged buildings at our disposition, Poznań's postwar situation was very difficult..$^{50}$ Zbigniew Zieliński (1907-1968) was an engineer and architect from Poznań. Before the war he had worked as an urban planner; after 1945 he became director of planning and development in the city's municipal government. Later, he acted as a consultant for for the Bureau for Urban Planning. In 1945 Zielinski estimated the damage as including 4,737 residential buildings, ${ }^{51}$ as well as 577 with economic uses, 272 trade and industrial buildings, and 246 public facilities. ${ }^{52}$ Kondziela $^{53}$ writes that altogether $55-60 \%$ of buildings in Poznań's Old Square were destroyed or damaged beyond repair. Konstanty Kalinowski estimated the destruction of the Old Square at around $45 \% .^{54}$

Although reconstructing the town seemed a complex and laborious task which 
could not be improvised, at the same time the haste of the moment compelled immediate action. It was necessary to remove rubble from the streets, to make the trams run again, to re-establish communications, telephone, gas, and electricity; and to repair housing and offices. Initially, work on these tasks was voluntary, anarchic, and driven by necessity.

Day by day the new political power assumed increasing responsibility. The communist government in Lublin had sent plenipotentiaries, who tried to control the situation in what they considered the right way. ${ }^{55}$ Even the process of reconstruction was coming to terms with the new power. As in Warsaw, a special bureau took over central controll and added a particular political connotation. The Poznań Reconstruction Board (P.D.O., Poznańska Dyrekcja Odbudowy) created in October 1945 was the equivalent to the Bureau for Reconstruction of the Capital Town (Biuro Odbudowy Stolicy). ${ }^{56}$ A report from June 1945 signed by the director of the Municipal Department of Construction claims the responsibility for setting up a centralized institution for the reconstruction. A letter from the architect Jan Cieśliński (then Poznańs vice-mayor) to the Minister of Reconstruction in Warsaw mentions a meeting in July between them to talk about the issue. ${ }^{57}$ A document of 12 October 1945 from the same ministry gave permission to Cieśliński to organize and direct the P.D.O., which it seems he had already begun to do. ${ }^{58}$ Cieśliński (18991967), born in Poznań, acted as one of the first organizers of the odbudowa, and was Poznań's vice-mayor for construction issues and first director of the P.D.O.. He later worked at Miastoprojekt, and collaborated on planning the reconstruction of the Poznań city center. ${ }^{59}$

In its first year, the P.D.O.'s main role was "the construction, reconstruction and enlargement of state buildings. By demand of the Municipal Government, also municipal buildings." ${ }^{60}$ In fact, it assumed wide functions of reconstruction, initially often without coordination with other local and regional organizations. The P.D.O. was liquidated in May 1950, probably coinciding with the new centralization process, which affected the whole state administration. ${ }^{61}$

Depending directly on the Ministry of Reconstruction, the P.D.O. also constituted a means for the new state power to penetrate life at the local (town) level. The same concept of reconstruction for the state and for the capital city would be repeated in Poznań, as an intent-conscious or not-to coordinate the new national image with the micro-reality. What is more, everyday activities could also be used to indoctrinate P.D.O. workers, giving them opportunities to learn new forms of ritual in their lives. Hence, although the P.D.O. from the beginning had participated as an organized institution in official celebrations like May Day or its own P.D.O. anniversary, the number of political festivities was increasing with time, to include such commemorations as Stalin's 70th birthday or the annual commemoration of the Russian Revolution. ${ }^{62}$

Relating to the form of odbudowa, the P.D.O. exhibited the same process of discussion, on a minor scale, that was taking place in Warsaw, at all-Polish levels. 
The disputes over the correct way to reconstruct the town and to decide what to do with the more or less destroyed monuments seem to be similar. Possibly, because of Poznan's smaller size, the situation appeared more concrete, with controversies revolving around particular buildings.

\section{Destruction and Reconstruction}

In the report ${ }^{63}$ of 8 August 1945, Zbigniew Zieliński offered a comprehensive view of the situation in Poznań. After a brief description of the pre-war city-whose representative forums and squares were, in his view, not completely of Polish character he criticized German urban development during the occupation, recounted wartime losses, and tried to show the damage as a well-planned action of the Nazis. ${ }^{64}$ Thus, the German churches and "other characteristic German buildings" still stood, whereas Polish churches, the cathedral, and Polish libraries lay in ruins. ${ }^{65}$ The impression the town might give would be false because "the German towers, this artificially grafted German verticality, so alien to the Polish spirit, still stand, and, in contrast, there are no Polish buildings and towers." ${ }^{.66}$

Therefore, Zielinski recommended that "one of the first patriotic and aesthetic postulates of urban planning" be the destruction of a number of buildings: German towers, the entire former Kaiser's Quarter, a school, and "many German churches." The town's architectural face should be completely Polish after the reconstruction, without any vestiges of the former German appearance. ${ }^{67}$

Zieliński predicted a brilliant future for Poznań, which had always been the most Polish of the Polish cities. It was destined to be the capital of the Recovered Lands. ${ }^{68}$ The engineer commented on Poznan's urban and economic prospects in a utopian way, but with a discourse free of socialist or communist language. Quite the opposite: petit bourgeois feeling and local patriotism characterized his comments. ${ }^{69}$

The degermanization of Poznan's silhouette constituted an important topic at the time. ${ }^{70}$ The folders of Poznańs municipal government contain a list of files, probably from the first half of 1945. The list refers to the Department of Reconstruction and shows how important the issue was: it engaged a special section of the Department in the removal of the rest of the Germanness [niemczyzny]." Also, in addition to the reconstruction of the destroyed buildings and the conservation of monuments, one of P.D.O.'s main tasks was the "degermanization of forms." " 2

After the experience of occupation and war, the psychological urgency of eliminating reminders of that terrible suffering is understandable. In response to a journalist's query, Jan Cieśliński, the Director of the P.D.O., affirmed that this journalist probably didn't spend the time of occupation in Poznan and that is why he doesn't understand what moral support was offered to us to see the Polish monuments, showing tenaciously, despite official propaganda, that Poznan was a Polish town. ${ }^{73}$ The emotional reaction to the sufferings of the Second World War can explain people's attitudes to buildings and presumed symbols of foreign rule, but in 
the case of Poznań a slightly different design emerges.$^{74}$ Henryk Kondziela writes that the decision on the reconstruction contained-as in Warsaw, Gdańsk, or Wrocław-a strong emotional component. It constituted a protest against the barbaric destruction of the war, which had far-reaching implications for Poznan. The protest was not limited to the last conflict but was also directed against Bismarck's Kulturkampf and the former Prussian occupation. The character of reconstruction had allegedly been decided not only by specialists (architects and curators) but also by Poznan's inhabitants and their patriotism. ${ }^{75}$

Since the new face of the town was intended to overcome the heritage of the German past, the architectonic style had to be connected to the older and purer Poland of pre-partition times. If the nationalistic inclinations in art before the war had been focused above all on folk and peasant culture, the new theories employed historical and architectonic styles such as Gothic, Renaissance, or classical. ${ }^{76}$ Unquestionably it was not a revival of the historicism of the nineties-neo-Gothic, etc.-but a real reconstruction of how buildings were supposed to have been or, even, should have been.

In an article in Skarpa Warszawska, the magazine about odbudowa published by the Bureau for Reconstruction of the Capital Town (B.O.S.) in Warsaw, Zofia Karczewska-Markiewicz praised the now destroyed Old Town of Poznań. For many generations, through maneuvers of savage germanization, [the Old Town] maintained the Polishness of Poznań. The reconstructed New Old Town would come to be a Medieval Monument with the rebuilt Renaissance Town Hall, cleansed of German additions. She explained that the architects working on Poznan's future profile were determined to erase the German past and thus the Kaiser's Castle had to vanish. ${ }^{77}$

The author labeled the castle the "Crusader's Castle", thus linking it with the hated German Order, the proverbial incarnation of one thousand years of enmity between Germans and Poles. ${ }^{78}$ Such symbolism had been used by the Kaiser's architects who built the castle, and the style of the building was reminiscent of the constructions of the almost mythological "German" warriors who, according to nineteenth-century historians, brought (German) "civilization" to the East. The Crusaders as a mythological enemy were also familiar to every Pole who had read nationalist novelist Henryk Sienkiewicz's The Teutonic Knights. ${ }^{79}$

Curiously, a Masurian delegation at the first meeting of the Association of Architects of the Polish Republic (S.A.R.P.) in Lublin, in November 1944, had proposed "to destroy, to demolish, to delete from the surface of the earth every Crusader's Castle, so that any trace would remain, and the reminders would disappear." ${ }^{80}$ It was apparently a Slavic —and Polish nationalist activist-delegation in view of the fact that the former East Prussian region Masuria had a mixed population with very labile identities. Thus, the feeling of bellicosity against a perceived alien architecture was present, though both Poznan's and Masuria's populations had grown up in the shades of Prussian architecture. Nevertheless, it has to be remembered that, for example, Hitler had visited and lived in Poznań's castle 
and the famous Crusader castle of Marienburg/Malbork.

The Kaiser's Castle became a centerpiece in the debate about the reconstruction in Poznań. A tourist guide from 1949 describes the discussion which many architects, urban planners and publicists have carried on the press and notes that numerous voices were raised for the complete removal of this gray and ugly German residue. ${ }^{81}$ Most Poznan architects wanted the castle—or at least its towers - to be demolished, as a survey of several important architects reveals. ${ }^{82}$ Roger SXawski (1871-1963) was a famous Poznan architect who had studied in Charlottenburg and developed his profession in Marburg, Karlsruhe, and Berlin. In Poznań he designed many public and private buildings, making a great contribution to Poznańs peculiar style. ${ }^{83}$ Kazimierz Ulatowski (1884-1975), who studied at Charlottenburg and Stuttgart, formed part of the Supreme Popular Council-a Polish political institution that seized the power in Poznań in 1918 - and took part in organizing the new Polish administration.

Perhaps because many of the architects had been born under Prussian rule, the Kaiser's Castle had a strong meaning for them. They had seen it built during the last years of German rule. Architecture constituted, even before Poland's independence, a battlefield for the national self-image of both Poles and Germans, and people like SXawski and Ulatowski had taken part in it. ${ }^{84}$ Both architects, acting in 1945 as consultants and planners for the municipal government, criticized the reconstruction project for not planning to destroy the castle. Ulatowski even looked for legitimization for his ideas in the feelings of the whole population of Poznan, whose views he thought should be respected. ${ }^{85}$.

A commission of experts, invited by the Minister of Reconstruction, advised the municipal powers about the reconstruction of the town center ${ }^{86}$ The commission comprised people working on a national level like the previously mentioned National Curator, Jan Zachwatowicz, some representatives of the B.O.S. and of the Minister of Reconstruction, as well representatives from Poznań. In a report of 17 November 1945, the experts tried to put rationality into the debate. They wanted the castle to stay and they based their decision on a long list of technical considerations rather than on emotions alone. The town's plastic profile had to be cleansed of every disturbing element—but no words about their Germanness were said-and an "eventual plebiscite" would decide the castle's fate. However, in the first meetingwhich took place a few days later, on 19 November-the experts could speak more freely about "this Prussian heritage, which every inhabitant of Poznań wanted to see transformed in a way which had not been reminiscent of its previous aspect, or dismantled at all. ${ }^{87}$

The dimensions of the building, however, were enormous and its demolition would have been really difficult, an irrational task in a city where the official facilities had, for the most part, been destroyed and where it was necessary to find places to house the diverse elements of administration. Even Poznań University and the municipal government came into conflict over the potential use of the castle. ${ }^{88}$ In the end, the 


\section{J. M. FARALDO}

local government won and the castle was transformed into the "New Town Hall." Since 1963, when it was renamed the Palace of Culture, it has been home to a variety of cultural institutions.

In the end, the necessities of the day prevailed. Ulatowski asked, rhetorically, whether utilitarian, present considerations were to predominate over concepts that would have a strong influence on the future centuries. ${ }^{89}$ The still standing castle's silhouette-in fact, the whole Kaiser's Quarter-seems to have responded to him with its presence. Practical necessities seem to have been more decisive than nationalist ideology. At least, this time.

\section{Searching For a Style}

The discussion about destruction was also supposed to be a debate about construction. A P.D.O. report from 1947-probably written to present in Warsaw to get loans for the reconstruction-affirms that "Poznań does not have too many monuments. Nevertheless, the significance of such monuments lay not only in their artistic value but also in their political-national value, because they suggested evidence of Poznań's Polishness..$^{90}$ Thus, it was clear that the Old Town had to be rebuilt as in Warsaw. But the problem of how to do it persisted. For many architects the pre-war structure of the quarter did not constitute the best possible solution. The buildings on the market square and the adjacent streets were Gothic in origin-this was hardly perceptible - and further developed in Renaissance, baroque or classical styles, in a form typical of central European Bürgerhäuser. Moreover, the late nineteenth and the early twentieth centuries had brought modernist department stores, neo-Gothic official buildings, extensive remodeling of the façades and a much criticized renovation of the Renaissance Town Hall. ${ }^{91}$ How would it be possible to rebuild such features, which were often so impure, so mixed, so transformed by past years?

The solution in Warsaw was to resort to a stylized classicism, although sometimes maintaining the pre-war exterior for the more important monuments-churches or palaces. This solution did not work for Poznań, where there were not many important classical masterpieces and perhaps because classicism had a strong connection with traditional Prussian buildings. ${ }^{92}$ SXawski, although not completely in accord with Poznań's interwar constructions, considered it unnecessary to employ the modern style imported from the big city Warsaw, a style that had its roots in German architectonic publications..$^{93}$ It was necessary to look at Poznańs Old Town for very old, very simple constructions and use them as models. They had to be " 150 or 200 year-old buildings with good proportions, rendered walls, tiles on roofs and Polish character." 94

However, Polish character was not so easy to define. It seemed inevitable that the constructions of the century under Prussian rule should be ignored, because they could not have had-in the Polish nationalist interpretation of Poland's history - a true "national" quality. In fact, there were proposals "to buy and to demolish the 
constructions of the nineteenth and twentieth century if they did not present adequate (Polish) characteristics for the quarter..$^{95}$ The solution to this problem appeared to be to look for architectonic forms of the sixteenth and seventeenth centuries-Poznan's golden age.

The new situation opened with the West and North Lands incorporation and the aim to ideologically legitimate the new borders had consequences for architecture. Poznań could be considered the symbolic capital of the old/new lands, the Ziemie Piastowskie, Lands of the Piasts," the first rulers of Poland..$^{96}$ The legendary Piast's state provided the legitimization for considering Wielkopolska to be the region where the medieval country had had its origin, and hence the region was supposed to maintain the most authentic essence of the Polish culture. Probably because relatively few Piast monuments still remained, it emerged that the style that could fit the real necessities better should be the Gothic. It is possible to find traces of this way of thinking in some buildings on the Old Market Square, for example, in Saint Martin's Church and, above all, in the cathedral.

St Peter and Paul's Cathedral was virtually destroyed in fighting during the last days of the occupation. This led to the discovery of basements in the building and provided a chance to research the cathedral's origins more accurately. It was established that the cathedral was older than had previously been supposed: vestiges of high medieval temples-pre-Romanesque, Romanesque, Gothic-were found. This served to develop the Piast mythology ${ }^{97}$ and to substantiate the discourse of selfconfidence in the values of "Polish culture," with words like "in the early Middle Ages our culture and civilization were higher than we ourselves thought." ${ }^{19}$ One writer remarked that the cathedral, "against German theories, was not inspired in the German Gothic, even not in the Prague's cathedral but had its own model." 99 Consequently, the decision was made to reconstruct the cathedral as a red-brick Gothic building. Though the pre-war cathedral had had a baroque façade, the new face of the building approximated the buildings of the Hanseatic towns of the Baltic. The re-gothicization of the cathedral took until 1956 (under the Catholic Church's auspicious, because the P.D.O. had ended its activities there in 1948, when Stalinist tendencies reached their zenith). ${ }^{100}$ The cathedral was a strong symbol of Catholicism, and state power, now concentrated in communist hands, probably did not want to endorse it.

The search for a national reconstruction style was long and contested. As late as 1952 or 1954 Zieliński and other collaborators in the Miastoprojekt affirmed that "for all the rebuilding or reconstructing elevations it is necessary ... to go back to the oldest documented architectonic forms, which date, with a few exceptions, from the eighteenth century." ${ }^{101}$ Nevertheless the authors linked the historic reconstruction with the assertion that the Old Market Square should be "one of the elements of socialist Poznań and include all the new technical developments. Moreover, the reconstruction of the polychrome on the façade was to be realized not in historic or pseudo-historic configuration but with contemporary motives and models. So, the 
next generation would have the impression that they see, on the façades of Poznan's buildings, pictures of 1955, that they look at art of the middle of the twentieth century, harmonized with elements of Poznań Renaissance, baroque and classicism. ${ }^{102}$ So, the socialism in architecture was associated-as in Warsaw or Gdańsk - with technical progress and comfort inside the buildings, and with the superficial approximation of the front walls to the actual fashion style. If in Stalinist times the reconstructions had a touch of socialist realism (above all Stalinist monumentalism), the stylized graphics on the walls reflected more rationalist and avant-gardist models.

\section{Waga Miejska}

The block in the middle of the Market Place constituted one of the cardinal problems of reconstruction. The Town Hall, the Guardroom, the Arsenal, the New Town Hall and some other old buildings formed an architectonic complex with political meaning. There was a long discussion of the problem and the decision-making process continued for years. ${ }^{103}$ Ulatowski's initial plan - to demolish many medieval structures and to construct a classical new building in the center of the square-was rejected. ${ }^{104}$ This plan had little chance of realization, even though the city's mayor more or less supported it, accusing other architects of being dreamers in love with the past. ${ }^{105}$

From the beginning, however, it was clear that one particular building in the middle block had to be destroyed: the so-called New Town Hall. Ulatowski himself said that "[during the interwar period] I often walked near the German new Town Hall and I was surprised that Poznań's mayor did not order it demolished." ${ }^{106}$ The war provided the opportunity to carry out this desire. A report on the activities of the P.D.O. for the period between 1 November 1945 and 31 December 1946 notes that the New Town Hall had been demolished. ${ }^{107}$ Some residue must have remained, because a municipal government protocol from 25 February 1948 stipulated the demolition of the rest of the New Town Hall (see Figure 2) ${ }^{108}$.

To expunge "alien" constructions was conceivable but what would be built in their place? In this case the solution was the rebuilding of the Town Scale, which had been demolished in 1890 to make place for the New Town Hall. This primitive building was put up around 1253 , remodeled many times and, in 1563 , totally reshaped by Giovanni Baptista Quadro, the Town Hall architect. ${ }^{100}$

It is difficult to say when or who suggested that it be rebuilt, ${ }^{110}$ but memories of the lost Town Scale were still living because the idea came up very early on and was not disputed. ${ }^{111}$ The project was revised many times, but it was completed. ${ }^{112}$

Again, as in Warsaw, to rebuild - to build anew-the object was a form of amendment of the past. Because "the Germans" had destroyed the primitive "Polish" Town Scale to build a "German" Town Hall, the Polish architects could now (re)create what they thought was necessary to reconstruct the town's Polish face. ${ }^{113}$ Thus, it is 


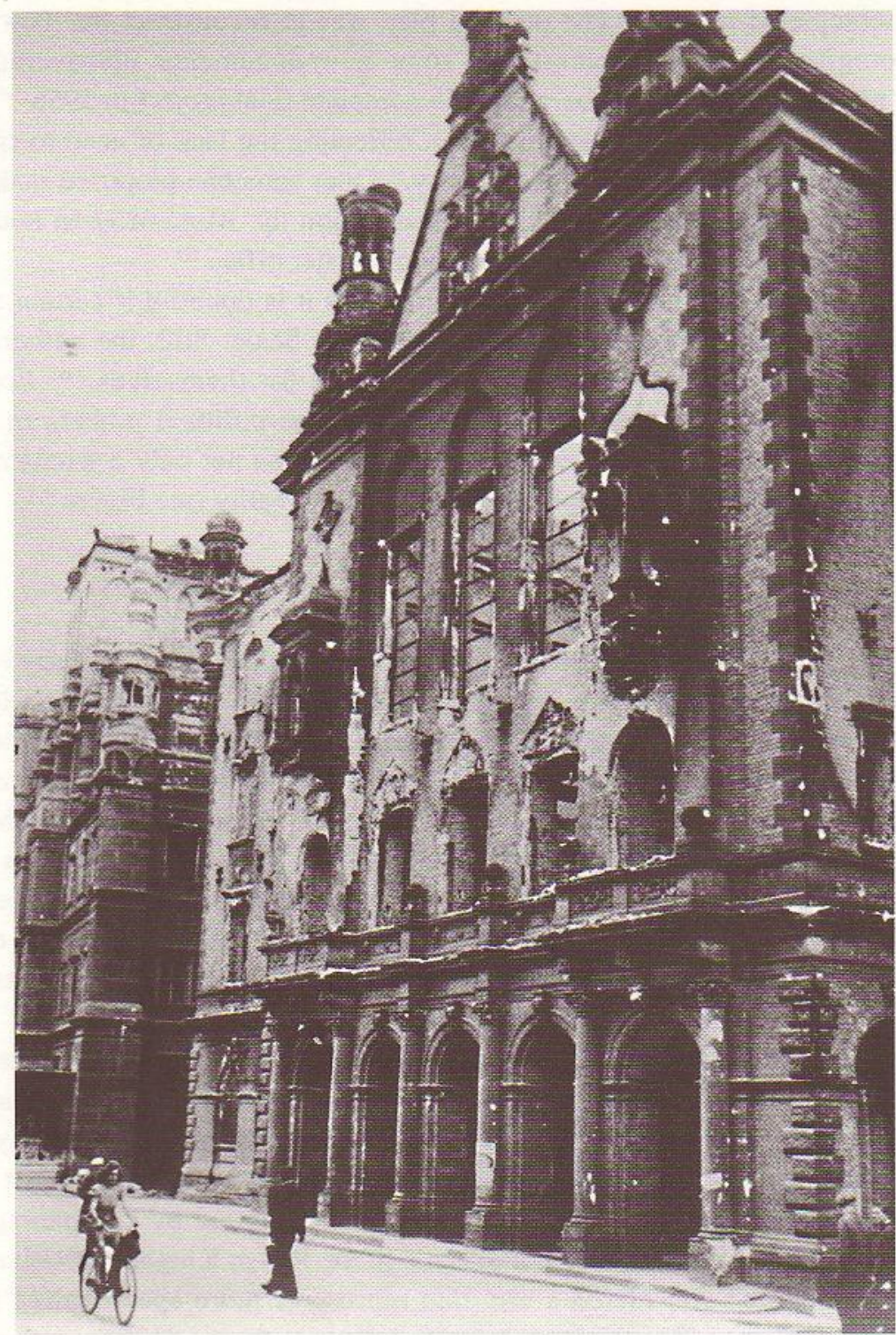

FIGURE 2

New Town Hall after 1945

(Photo: Archiwum Miejskiego Konserwatora Zabytków, Kartoteka, Poznań).

not a surprise that the tourist guide of 1949 had a description of the Town Scale-a building that had been gone for almost 60 years. ${ }^{114}$

In 1948, Poznań's municipal government approved the first blueprint of the Town Scale, Roger Sławski's and Zbigniew Zieliński's design. ${ }^{115}$ Work began only in 1958 
and was completed in 1960. The original plan was to reconstruct the Town Scale from photographs and old pictures, but some new documents, discovered in the National Museum, led to the elaboration of a complete final project in $1956 .{ }^{116}$

The use of the building remained unclear, reflecting the lack of need to construct it. First it was planned to be a "Soviet library." Later someone proposed making it a part of the Municipal Museum. Following completion the Waga Miejska housed the Western Institute, but it is presently the Poznan register office. ${ }^{117}$

A report on the Old Town asserts that sometimes it is doubtful if certain extreme reconstructions make sense, for example, the Town Scale. Still, the author admits that doubts disappear when we look at the objects for themselves." ${ }^{118}$ Economic rationalism seems inadequate to understand why the political powers in Poland dedicated so much effort and so many resources to shape not only a whole range of different lost buildings but a completely new nostalgic reality (see Figure 3 ).

\section{Poznań in Polish Context}

Poznan, like a great number of towns in Poland, can be considered an early example of Cities of Collective Memory, in M. Christine Boyer's words; places where the historical imagination uses the architectonic fragments of the past taken "by nostalgic sentiments that fuel their preservation or reconstruction, while our collective memory of public places seems undetermined by historicist reconstruction." ${ }^{119}$ The postmodern architecture of the 1980s and 1990s with its architectural references and its return to intimacy and traditions was, in a certain sense, anticipated by the Polish odbudowa. We see this relationship clearly if we consider the reconstruction of some Polish cities in the 1890s, such as Głogów, where the new Old Town looks like a Disneyland-like opus of the New Architecture.

How representative is Poznań? Lying on the borders of the Polish territories and closely connected to German culture and history, it might not seem comparable to other Polish cities. But, perhaps, there is no absolute representative Polish city in this sense. Wrockaw has an important German component in its past. The port city of Gdańsk was always linked to the Polish state but inhabited by German-speaking peoples, and Warsaw played an important role in the Polish Kingdom relatively late. Only Cracow can be considered a city that represents more specifically "Polish" culture. Nevertheless - if we neglect Austrian influence there-Cracow was a model for eastern Polish cities, many of which are now a part of Ukraine and connected to the national imagination of Ukrainians too.

Maybe the specificity in Polish culture was the capacity to create effective signs of self-identification in territories and landscapes disputed with other concurrent cultural traditions. This signs were so mighty that they left the communists little space to introduce new ones, although they did. The main role of the communists was to disseminate and generalize signs of identity - the mission of every nationstate-and they performed this task with great zeal, assuming the Piastic view of 


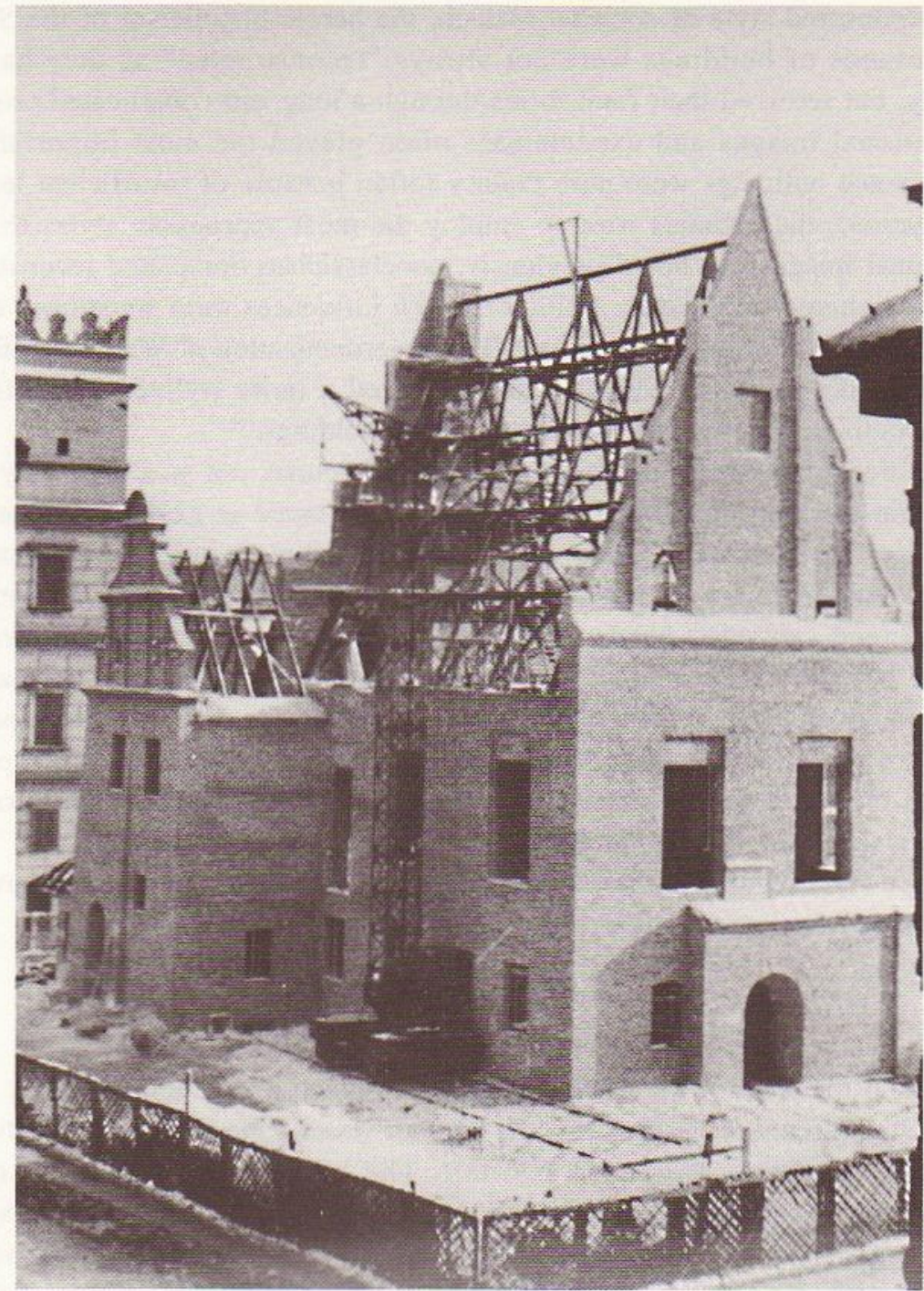

FIGURE 3

The reconstruction of the Municipal Scale, 1958

(Photo: Archiwum Miejskiego Konserwatora Zabytków, Kartoteka, Poznań).

Polish history as the best way to connect the national symbolic with their social mission.

Throughout the Polish landscape, many towns and village were reconstructed and re-elaborated to define a new nation, principally employing old signs or, more accurately, projecting their interpretation of the old signs. For the Polish communist the reconstruction of Old Towns was easy to accept because it could be connected to 
the state-sponsored style of socialist realism, the heroic historicism of the Stalinist era. Thousands of buildings were not always "reconstructed" as they had been previously, but received their final forms through a long and complicated process in which national images and expectations often played the most important role. Although some buildings were pure fantasy (often because of insufficient technical documentation), the planners tried to employ the most appropriate styles to reflect their national images. As noted previously, neoclassicism dominated reconstruction in Warsaw, whereas in Gdańsk, Baltic or Dutch influences were sometimes emphasized in order to avoid the German past. The degermanization of Wrockaw failed and other cities, like Sczeczin and Stargard, received a more stylized reconstruction based on completely new-but often archaized-buildings. ${ }^{120}$

The plastic expression of national images is, of course, not an exclusively Polish phenomenon. In a strong nationalist sense we could name as examples some of the "new villages" in Francisco Franco's Spain. The partial reconstruction of Dresden, in the former East Germany, has a similar pathos of national resistance to destruction by foreign (and capitalist) hands to that of Warsaw. There is, however, a relevant difference between the search of postwar West Germany for a new national selfimage (through an urban reconstruction of modern, light, and open forms) and some forms of (re)invention of an archaic Polish past, which even some contemporaries considered bizarre ${ }^{121}$ In this context, the fact that the most hated Stalinist construction in Warsaw (the skyscraper known as PKiN) contains an element of "Polish Renaissance style," should be not considered a huge Stalinist joke, but as part of the concern for developing communist national visions.

\section{Conclusion}

Sometimes at the door of the Town Scale, one can see people coming back from a civil marriage ceremony. In their joy, they do not waste a moment thinking about the origin of the building they have just left. The "Palace of Marriages" or "the Registry," represents only one part of the monumental Old Town: a usual spot for tourists to take photographs and a fine place to eat-in the restaurant in its basement-very good Polish meals. Reminders of the rebuilding subsist only as a footnote in tourist guides or scholars' writings (see Figure 4).

Today, the Kaiser's Castle no longer reminds the people of Poznań of a foreign power's yoke or a foreign occupier. Serving as a House of Culture, with cinema, theater, exhibition, and concert halls, the Zamek (Castle) represents only a typical post-socialist culture object, a reminder of the time when culture was cheap, state run, and saturated with meaning. The interior of the castle was redesigned and redecorated in the "goulash socialism" style of the late 1960s and 1970s, and it is possible to find vestiges of Gomulka's nationalistic ideology in such objects as the long frieze about Poznan's history which celebrates the millennium of the Polish state. ${ }^{122}$ 


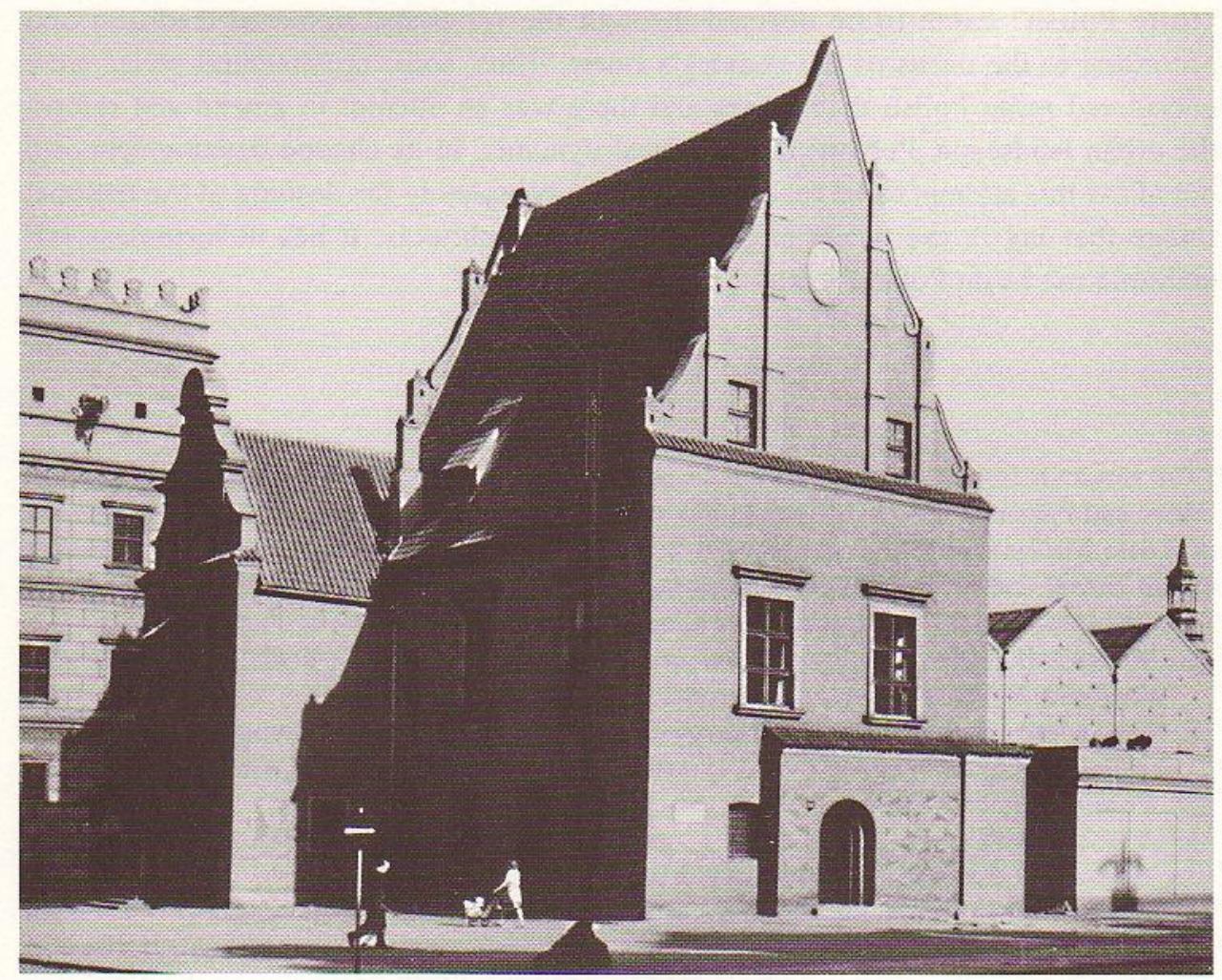

FIGURE 4

The new Municipal Scale, 1961

(Photo: Archiwum Miejskiego Konserwatora Zabytków, Kartoteka, Poznań).

So, in a sense, the intent of Poznan's - in general, Poland's - rebuilders to shape a special, concrete reality and to erase all traces of the German past was successful. The new nation born from the ashes of wartime Poland is one of the more homogeneous nation-states in Central Europe. From the beginning, the process of reconstruction-and creation-of monuments and residential quarters was linked to resistance and protest against the occupation and the destruction during the conflict. Just as importantly, the process of reconstruction was also associated with the vision of a new country, free of the errors of the past. In western and northern Poland, reconstruction acted as a means of polonization and of the legitimization of Polish administrators capacities to govern the former German territories. ${ }^{123}$

In Poznań, perhaps owing to the town's special tradition and the national friction during the partitions and the interwar period, the urge to erase the alleged German past was very strong. It supposed a particular definition of the image the people had of themselves and of their town and the intent to shape an ideal prototype of a Polish city whose profile standing out against the horizon was truly Polish. The meaning of 


\section{J. M. FARALDO}

"truly Polish" came to be defined through the local and national tradition and according to the needs of the country's rulers. Thus, some architectural styles were considered more Polish than others and there was an attempt to amend and reform the urban landscape. Perhaps the historical dynamic, in its chaotic development, did not allow this attempt to be realized following completely the designs of the national image that lay in the heads of politicians and architects. It has nevertheless left enduring marks on Poland's skin.

\section{NOTES}

*The research for this article was made possible by a scholarship of the Spanish Foreign Office and Poznań University. I would like to remember the late Professor Edmund Makowski of Adam Mickiewicz University, for his help when I was in Poznań. I also thank Professor Stefan Kowal and Professor Jan Skuratowicz of Adam Mickiewicz University, Gregor Thum, Torsten Lorenz and the anonymous reviewers of Nationalities Papers for their comments.

1. Moritz Jaffé, Die Stadt Posen unter preußischer Herrschaft. Ein Beitrag zur Geschichte des deutschen Ostens (Leipzig: Duncler \& Humblot 1909), p. 409.

2. The richest view of Poznań's history-although unfinished-is contained in the volumes of Dzieje Poznania, edited by the late Jerzy Topolski. Another useful source is the journal Kronika Miasta Poznania.

3. A good work about this revolt is Antoni Czubiński, ed., Powstanie Wielkopolskie 1918-1919. Zarys dziejów (Warsaw: PWN, 1988).

4. There is much important literature on Prussian Poland and the resistance of its (Polish nationalist) inhabitants to the Prussian boot. The (German) nationalist movements in Poznań are well studied too. The formation of national consciousness-or the defense of an alleged pre-existing one-the loyalty of Poznan Poles to the King/Kaiser, and the many labile, neutral identities have received little attention. As examples of exceptional treatments of theses themes see: Rudolf Jaworski, Handel und Gewerbe im Nationalitätenkampf: Studien zur Wirtschaftsgesinnung der Polen in der Provinz Posen (1871-1914) (Göttingen: Vandenhoeck \& Ruprecht, 1986); and Mathias Niendorf, Minderheiten an der Grenze. Deutsche und Polen in den Kreisen Flatow (Zlotów) und Zempelburg (Sẹpolno Krajeńskie) 1900-1939 (Wiesbaden: Harrassowitz, 1997).

5. See Zdzisław Grot, "Dzieje pomnika Mickiewicza w Poznaniu 1856-1939," Przeglad Zachodni, No. 1, 1949, p. 457. This-and other similar monuments to Mickiewicz-were destroyed by the Nazis. In 1960 another statue was built, although with a very different form. See Irena Grzesiuk-Olszewska, Polska rzeźba pomnikowa w latach 1945-1995 (Warsaw: Neriton, 1995), pp. 280-281.

6. Jan Skuratowicz, Architektura Poznania 1890-1918 (Poznań: Wydawnictwo Naukowe UAM, 1991), pp. 208-242.

7. Poznań's International Fair of Industry and Commerce (MTP) played this function before the war in a similar way as it did it in socialist times. See Bohdan Danielewski, Z dziejów Międzynarodowych Targów Poznańskich (1921-1971), Kronika Miasta Poznania, No. 2, 1971, pp. 15-32.

8. Greater Poland's Jewish population was reduced during the nineteenth century, because Jews moved westward, principally to Berlin. The Jews who stayed increasingly identified themselves with the Germans. During the interwar period Poznań's Jewish community grew but it remained relatively small. See Ireneusz Kowalski, Poznańska gmina żydowska 
w latach II Rzeczypospolitej," Kronika Miasta Poznania, Nos 1/2, 1992, pp. 81-101. Concerning the ethnic composition of Poland: Poles constituted some $65 \%$, Ukrainians $16 \%$, Jews $10 \%$, White Russians $5 \%$, Germans $3 \%$, and $1 \%$ were other minorities (Czechs, Russians, Lithuanians, etc.). See Jerzy Tomaszewski, "The National Question in Poland in the Twentieth Century," in Mikulás Teich and Roy Porter, eds, The National Question in Europe in Historical Context (Cambridge: Cambridge University Press, 1993), pp. 293-316, here p. 306. Tomaszewski employed the 1931 census.

9. See Niels Gutschow, "Stadtplanung im Warthegau, 1939-1944," in M. Rössler and S. Schleiermacher, eds, Der "Generalplan Ost" (Berlin: Akademie Verlag, 1993), pp. 233-258; and Niels Gutschow and Barbara Klein, Vernichtung und Utopie. Stadtplanuñg Warschau 1939-1945 (Hamburg: Junius Verlag, 1994), pp. 41-47.

10. A interesting comparative view of European interwar monumentalism is Franco Borsi, Die Monumentale Ordnung. Architektur in Europa, 1929-1939 (Stuttgart: V. Gerd Hatje, 1986).

11. During the war, Poznan lost between 45,000 and 50,000 Polish residents. See Tadeusz Świtala, ed., Trud pierwszych dni. Poznań 1945. Wspomnienia Poznaniaków (Poznań: Wyd. Poznańskie, 1970), p. 27. The total number of inhabitants before 1939 had been around 275,000 .

12. There are numerous new works on the establishment of the communist regime in Poland. Most of them present it exclusively as a foreign (Soviet) imposition, a thesis that is not entirely sustainable. The socialist system was not only part of Stalin's foreign politics; it had grassroots support, too. See Krystyna Kersten, Między wyzwoleniem a zniewoleniem. Polska 1944-1956 (London: Aneks 1993); Andrzej Palczak, Procesy stalinizacji w Polsce w latach 1947-56 (Zabrze: Wyd. Apex, 1996); Janusz Wrona, System partyjny w Polsce, 1944-1950 (Lublin: Wyd. Uniwersytetu Marii Curie-SkYodowskiej, 1996). For a comparative perspective see Norman Naimark and Leonid Gibianskii, eds, The Establishment of Communist Regimes in Eastern Europe, 1944-1949 (Boulder: Westview Press, 1997); and Ulrich Herbert and Axel Schildt, eds, Kriegsende in Europa. Von Beginn des deutschen Machtzerfalls bis zur Stabilisierung der Nachkriegsordnung 1944-1948 (Essen: Klartext Verlag, 1998).

13. See Gomulka's early postwar writings, like Nowa karta dziejów Polski [discourse of July 1945]. See WXadysław Gomułka, Artykuly i przemówienia, t. 1, 1943-45 (Warsaw: Książka i Wiedza, 1962), pp. 310-338.

14. On nation building in Poland and East Central Europe, see Józef Chlebowczyk, On Small and Young Nations in Europe. Nation-Forming Processes in Ethnic Borderlands in EastCentral Europe (Wrocław: Ossolińskich, 1980). The best analysis of nationalism in Poland (up to the begin of the twentieth century) is Tomasz Kizwalter, O nowoczesności narodu. Przypadek Polski (Warsaw: Semper, 1999).

15. On communism as a form of developmental nationalism, see Marcin Kula, Komunizm (niekiedy) bardzo narodowy, Przeglad Polonijny, No. 2, 2000, pp. 7-24.

16. Marcin Zaremba, Próba legitymizacji wYadzy komunistycznej w latach 1944-1947 poprzez odwolanie się do treści narodowych," in Polska 1944/45-1989. Studia $i$ materialy, t. 2, 1997, pp. 35-62; "“Polski naród socjalistyczny'-legitymizacja nacjonalistyczna w okresie stalinowskim," Kultura i Spoleczeństwo, Vol. 41, No. 4, 1997, pp. 117-136.); and Piotr Madajczyk ("Polska Myś Zachodnia w polityce komunistów polskich," Przeglạd Zachodni, No. 3, 1997, pp. 15-36) seem to prefer this interpretation. Indeed communist national rhetoric and tactics are a good partial explanation for concrete moments but not for the whole problem.

17. Western Thought (Mysl Zachodnia), a pre-war Polish nationalist movement that 


\section{J. M. FARALDO}

advocated Poland's expansion to the west, was assumed by the postwar Polish communists (see Madajczyk, Polska Myśl Zachodnia). Another example could be Boleslaw Piasecki's postwar activities. Piasecki, a Polish fascist and anti-Semite, came to terms with the communist rulers after the war and became the leader of a national-catholic legal organization, Pax, which was very active in the 1968 anti-Semitic storm. See Lucian Blit, The Eastern Pretender (London: Hutchinson, 1965); and Antoni Dudek and Grzegorz Pytel, Bolesław Piasecki. Próba biografii politycznej (London: Aneks, 1990).

18. See Kaja Kaźmierska, Doświadczenia wojenne Polaków a kstaltowanie tozsamości etnicznej. Analiza narracji kresowych (Warsaw: Wyd. IfiS PAN, 1999).

19. For the context, see Piotr Eberhart, Międze Rosja a Niemcami, Przemiany narodowosciowe w Europie Środkowo-Wschodniej w XX wieku (Warsaw: PWN, 1996); for the Kresy, see Wojciech Wrzesiński, ed., Miedze Polską etńiczna a historyczna (Wrockaw: Ossolineum, 1988).

20. An important web of scientific institutes, state institutions, and even grassroots associations worked to "nationalize" the new territories through publications, activities, festivities and propaganda in every possible form. See, for example, Leopold Gluck, Od ziem postulowanych do ziem odzyskanych (Warsaw: Instytut Wydawniczy Pax, 1971); and Malgorzata Ujdak, Udzial Polskiego Związku Zachodniego w rozwiązaniu kwestii narodowościowej na ziemiach odzyskanych (Katowice: Uniwersytet Śląski: 1988).

21. See Grzegorz Strauchold, Polska ludność rodzima ziem zachodnich i pólnocnych. Opinie nie tylko publiczne lat 1944-1948 (Olsztyn: Ośrodek badań naukowych im. Wojciecha Ketrzyńskiego, 1995).

22. Kazimierz Pudlo, "Polityka państwa polskiego wobec ludności ukraińskiej (1944-1991)," Sprawy Narodowościowe, Vol. 2, No. 1, 1993; and Anna Adamus-Matuszyńska, "Influence of History on Social Consciousmess, Social Identity and Social Action: The Case of the Ukrainian Minority in Poland," in Marek S. Szczepański, Ethnic Minorities and Ethnic Majority. Sociological Studies of Ethnic Relations in Poland (Katowice: Uniwersytet Ślaski, 1997), pp. 224-243.

23. See, for example, Archiwum Akt Nowych, Warszawa (hereafter AAN), Ministerstwo Administracji Publicznej 774, pp. 89-90.

24. On "repolonization," see Bernard Linek, "Odniemczanie" województwa ślaskiego w latach 1945-1950 (w świetle materialów wojewódzkich) (Opole: Instytut Ślạski, 1997); and Gregor Thum, "Cleansed Memory: New Polish Wrocław and the Expulsion of the Germans," in Hunt Tooley and Stephen Vardy, eds, Ethnic Cleansing in Twentieth Century Europe (Boulder: East European Monographs, forthcoming, 2001).

25. The church was a nationalistic force by itself but it is interesting to see how a communist government promoted the publication of Polish-language prayer books, as a means to inculcate Polishness. See AAN, Ministerswo Administracji Publicznej 774, p. 103.

26. On this process in the northern and western regions, see Grzegorz Strauchold, "Próba stworzenia jednolitego społeczeństwa ziem zachodnich i północnych w powojennej dekadzie, Borussia, No. 22, 2000, pp. 73-80.

27. There are many works on the reconstruction but most are out of date. No good new analysis of the whole process exists. Jan Gorski's book on Warsaw (Warszawa w latach 1944-49. Odbudowa [Warsaw: PWN, 1988]) is a well-documented work about the most important example of reconstruction. The best understanding of the phenomenon is Konstanty Kalinowski, "Der Wiederaufbau der Altstädte in Polen in den Jahren 1945-1960," Österreichische Zeitschrift für Kunst und Denkmalpflege, Vol. 23, 1978, pp. 81-93. See also David Crowley, "People's Warszawa/Popular Warszawa," Journal of Design History, Vol. 10, No. 2, 1997, pp. 203-223. (I am in debt to Mr Crowley for 
sending me his valuable piece.) A recent contribution in English is Padraic Kenney, Rebuilding Poland: Workers and Communists, 1945-1950 (Ithaca, NY: Cornell University Press, 1997).

28. For West Germany, see for example, Arnold Sywottek and Axel Schildt, eds, Modernisierung im Wiederaufbau. Die westdeutsche Gesellschaft der 50er Jahre (Bonn: Dietz, 1993).

29. On scientists' and professors' Nazi engagement, see Götz Aly and Susanne Heim, Vordenker der Vernichtung (Frankfurt: Fischer, 1993).

30. On Ostforschung, see Michael Burleigh, Germany Turns Eastwards: A Study of Ostforschung in the Third Reich (Cambridge: Cambridge University Press, 1988). Zeitschrift für Ostmitteleuropaforschung, Vol. 46, No. 3, 1997 contains various articles on the subject.

31. There is very little literature on deutsche Kolonialkunst. See a definition of the concept by N. von Holst, "Kunst des Baltenlandes-deutsche Kolonialkunst," in Vol. 1, No. 3, Der Deutsche im Osten I:3, 1938-1939, p. 20. See also Adam S. Labuda, "Kolonizacja wschodnia i sztuka gotycka. Pojęcia i rzeczywistość, Artium Quaestiones, No. 6, 1993, pp. $45-52$.

32. An important contribution to the literature is Czesław Madajczyk, Die Okkupationspolitik Nazideutschlands in Polen, 1939-1945 (Berlin: Akademie Verlag, 1987).

33. For example, Zbigniew Zieliński, an engineer working in 1945 at Poznań's municipal government, who had also worked there during the occupation, described this work as zniemczenia (germanization) and spoke of pseudo-giant works and of the beginning of the restoration of the Old Town with disastrous consequences. See Archiwum Państwowe miasta Poznania [hereafter APP], Zarząd Miejski m. Poznania, Wydzial Budownictwa, t. 85 , p. 2: Uwagi do planu zabudowania m. Poznania. Speer's monumental neoclassical style remained dominant in Nazi plans for Poznań, but also in the Old Town there were traces of German folk architecture (the so-called Heimat style).

34. Cited by Michael A. Hartenstein, Neue Dorflandschaften. Nationalsozialistische Siedlungsplanung in den "eingegliederten Ostgebieten" 1939-1944 (Berlin: Verlag Dr. Köster, 1998), pp. 445-446.

35. Hitler has been quoted as saying that a people lives so long as the products of their culture live. See Jan Zachwatowicz, Przeszlość w slużbie nowego życia, Skarpa Warszawska, No. 2, 1945, p. 7.

36. In the middle of the year 1944, Wolna Polska, the newspaper of the Union of Polish Patriots (a Polish exiles' organization in the U.S.S.R.), began dealing with the problem of reconstruction in a context where "Poland can not be as it was in the past if we are not to repeat the experience of 1939 again." See, for example, Wolna Polska, No. 17, 1944, p. 2.

37. "Socialist reconstruction" was the key phrase of the epic Soviet industrialization in the 1930s.

38. See, for example, Zachwatowicz, Przeszlość.

39. See Bohdan Rymaszewski, O przetrwanie dawnych miast (Warsaw: Arkady, 1984), pp. 92-93; and Marta Leśniakowska, Polska historia sztuki i nacjonalizm, in Dariusz Konstantinow, Robert Pasieczni and Piotr Paszkiewicz, eds, Nacjonalizm $w$ sztuce $i$ historii sztuki 1789-1950 (Warsaw: IS PAN, 1998), pp. 33-59, here pp. 58-59. In addition to the political or architectonic discussion there was also the perception of the unnecessary economic expense in a collapsed country.

40. Piwocki, historian of architecture, responded to his critics in "Uwagi o odbudowie zabytków," Biuletyn Historii Sztuki i Kultury, Nos 1-2, 1946, pp. 53-59. Wyka was a famous literary and art critic. See his polemic "Miecz Syreny," Odrodzenie, No. 22, 1945, p. 8. 
41. A recent exhibition catalogue includes interesting biographic and pictorial material on Zachwatowicz. The new official version of history, however, attempts to turn him into a sort of resister of communism, which he was not, and of Warsaw's reconstruction, an epic odyssey of national renaissance opposing the "perverse communists" who really wanted to eliminate Old Warsaw. See Jan Zachwatowicz. W stulecie urodzin (Warsaw: Zamek Królewski w Warszawie, 2000). See also "Walka o pomniki kultury," AAN Ministerstwo Informacji i Propagandy, t. 697, pp. 14-20.

42. AAN, Ministerstwo Informacji i Propagandy, t. 697, p. 16. The article deals with Warsaw's reconstruction but it can be understood in a more general sense.

43. Art historian Micha $\chi$ Walicki polemised about this with both Kazimierz Wyka and Edward Osmańczyk, a journalist and, before the war, a nationalist activist. See Skarpa Warszawska, No. 1, 1945, pp. 5-6; and Odrodzenie, No. 23, 1945, p. 7.

44. AAN, Ministerstwo Informacji i Propagandy, t. 697, p. 18.

45. Leśniakowska, "Polska historia sztuki," p. 45.

46. See Rymaszewski, O przetrwanie, p. 95, Konstanty Kalinowski, "Der Wiederaufbau," p. 92 and Anders Åman, Architecture and Ideology in Eastern Europe during the Stalin Era (New York: MIT Press, 1992), especially chapter 6.

47. Henryk Kondziela, Stare Miasto w Poznaniu (Poznań: Wyd. Poznańskie, 1971), p. 53.

48. On the first days of the new regime in Poznań, see Trud Świtala and Ignacy Kaczmarek, Na gruzach Poznania w roku 1945, Kronika Miasta Poznania, No. 2, 1958, p. 49-53.

49. Jerzy Majewicz and Tomasz Markiewicz, Warszawa nie odbudowana (Warsaw: Wydawnictwo DiG, 1998), a book with abundant photographic documentation. This work, however, lacks real understanding of the architectonic decisions and priorities of the early postwar moment.

50. For example, an unpublished memoir, housed at the Western Institute in Poznań (Pamiętniki Mariana Rosady, signature P55, p. 3), claims that the situation in Poznań was more difficult than in Cracow.

51. Analysis of this is in Stanisław Waszak, Warunki mieszkaniowe w zniszczonym Poznaniu, Kronika Miasta Poznania, No. 3, 1948, pp. 215-225.

52. APP, Zarzạd Miejski m. Poznania, Wydzial Budownictwa, t. 85, pp 1-12.

53. See Wojciech Kalinowski, ed., Zabytki urbanistyki $i$ architektury w Polsce. Odbudowa $i$ konserwacja, t. 1. Miasta historyczne (Warsaw: Arkady, 1986), p. 363.

54. Kalinowski, Der Wiederaufbau, p. 81.

55. Like Michal Gwiazdowicz, who arrived at Poznań with his group on 3 February and performed the functions of regional governor. See Boleslaw Pleśniarski, W budynku dawnego gimnazjum przy ulicy Focha, in Świtala, Trud, pp. 227-248. Also: Eugenia Podbierowa, Ustrój wladz miejskich miasta Poznania i glówne kierunki ich dzialalności w latach 1945-50 (Poznań: Wyd. N. UAM, 1967).

56. There were five special reconstruction organizations (in Gdańsk, Poznań, Wrocław, Warsaw, and Szczecin) as well as the first special organization, the famous B.O.S. (Biuro Odbudowy Stolicy). See APP, Poznańska Dyrekcja Odbudowy, t. 1a (hereafter PDO). This folder contains a really good report written in 1947 by Witold Maisel—an official in the P.D.O.-about the organization of the whole process of reconstruction.

57. The Ministry of Reconstruction was established by decree on 24 May 1945 .

58. APP, PDO, t. 6, p. 27.

59. On urban planning in Poznań, see Witold Maisel, Ewolucja planów urbanistycznych miasta Poznania w latach 1945-1957, Kronika Miasta Poznania, No. 3, 1958, pp. 5-37.

60. Report about P.D.O. activities from 1 October 1945 to 31 December 1946, APP, PDO, t. 16 , pp. $1-4$. 
61. See APP, PDO, t. 7, p. 66.

62. APP, PDO, t. 20, passim.

63. APP, Zarzạd Miejski m. Poznania, Wydzial Budownictwa, t. 85, pp 1-12.

64. APP, Zarzạd Miejski m. Poznania, Wydzial Budownictwa, t. 85, pp. 3-4. That is one of the few mentions I have found of a planned devastation of Poznan. Was Zielinski trying to imitate the discourse about Warsaw, even unconsciously? Or were there Nazi plans to set Poznań on fire?

65. It was possibly very clear for Zieliński, as for the rest of Poznań's inhabitants, what a German building was: one constructed by Germans, inhabited by Germans, and used by Poznań's Germans. Surely, differences of style were very marked only in religious buildings, because most of the Germans were Protestants, which meant their churches were different than those of the predominantly Roman Catholic Poles.

66. The verticality of Germanness is again a reference to the churches of the German postunification style and of historicist (neo-Gothic) constructions. Gothic was considered the "most German" of all styles. See Francastel's known critical work (published in 1945!), "The History of Art, Instrument of German Propaganda," which was published in 1970 with a new title "Frontiers of Gothic." Pierre Francastel, L'histoire de l'art, instrument de la propagande germanique (Paris: Libr. de Médicis, 1945).

67. APP, Zarzạd Miejski m. Poznania, Wydzial Budownictwa, t. 85, p. 4.

68. APP, Zarząd Miejski m. Poznania, Wydzial Budownictwa, t. 85, pp. 5-6. Recovered Lands or North and West Lands refers to the former German lands that Poland acquired after the Second World War. Poznań was not actually part of them but because of its position between regained Pomerania and Silesia, some intellectuals from Poznań took to the idea.

69. In the sense of Vera Dunham, In Stalin's Time. Middle Class Values in Soviet Fiction (Cambridge: Cambridge University Press, 1976).

70. On degermanization and polonization, see Gregor Thum, "Bollwerk Breslau. Vom 'Deutschen Osten' zu Polens 'Wiedergewonnenen Gebieten,'” in Helga Schultz, ed., Das Ende der deutsch-polnischen Nachbarschaft (Berlin: Verlag Berlin-Brandenburg, forthcoming 2001); and Bernadetta Nitschke, Wysiedlenie ludności niemieckiej z Polski w latach 1945-49 (Zielona Góra: WSP, 1999), pp. 120-134.

71. APP, Zarzạd Miejski m. Poznania, Wydzial Budownictwa, t. 42, pp. 47-52.

72. APP, PDO, t. 6, pp. 3-9.

73. APP, PDO, t. 16 , p. 7.

74. See Krystyna Kersten, Miẹdzy wyzwoleniem a zniewoleniem. Polska 1944-1956 (London: Aneks, 1993) p. 11.

75. Kondziela, Stare Miasto, p. 12.

76. A brilliant study of the rich national tendencies in art and design in Poland before the Second World War is David Crowley, National Style and Nation-State. Design in Poland from the Vernacular Revival to the International Style (Manchester: Manchester University Press, 1992).

77. Zofia Karczewska-Markiewicz, "Miasto leczone sercem ludu," Skarpa Warszawska, No. 8,1945 , pp. $1-2$, here p. 2 . The Ratusz acquired its principal aspect after a fire in 1536. The Italian Giovanni Baptista Quadro rebuilt it between 1550 and 1560 as a beautiful example of the Polish Renaissance. See Henryk Kondziela and I. Jasiecka, Przeglạd zabytków miasta Poznania (Poznań, 1965), pp. 19-20; and Teresa Jakimowicz, Jan Baptysta Quadro z Lugano-Architek (Poznań, 1998).

78. This was the title for a planned exhibition in Poznan, which was to present the eternal enmity between the two peoples (the title comes from a book by Zygmunt Wojcie- 
chowski, a pre-war nationalist and the Western Institute's first director). The exhibition never took place but it is considered a precedent to the later, famous Exhibition of the Recovered Lands in Breslau. See Jakub Tyszkiewicz, Sto wielkich dni Wroclawia. Wystawa Ziem Odzyskanych we Wroclawiu a propaganda polityczna Ziem Zachodnich $i$ Pólnocnych w latach 1945-1948 (Wrocław: Arboretum, 1997) pp. 71-77; and on Wojciechowski, see Marian Mroczko, Zygmunt Wojciechowski jako historyk polskich ziem zachodnich oraz stosunków polsko-niemieckich, Przeglad Zachodni, No. 1, 1985, pp. 98-113.

79. The still popular novel was filmed in 1960 and, as a result, the story became even more popular. See José M. Faraldo, "The Teutonic Knights and the Polish Identity. National Narrativès, Self-Image and Socialist Public Sphere," in Gabor T. Rittersporn, Jan C. Behrends and Malte Rolf, eds, Sphären von Öffentlichkeit in Gesellschaften sowjetischen Typs (Frankfurt/N.Y.: Peter Lang).

80. Cited in Józef Sigalin, Warszawa 1944-1980. Z archiwum architekta, t. 1 (Warsaw: PIW, 1986), pp. 28-29.

81. Poznañ. Przewodnik po mieście (Poznań: Wyd. Zachodnie i Morskie, 1949), p. 53.

82. See for example, APP, Zarzạd Miejski m. Poznania, Wydzial Budownictwa, t. 86, pp. 1-3, 4-8.

83. See Wielkopolski Slownik Biograficzny, p. 676; and, above all, Skuratowicz, Architektura, pp. 352-353.

84. Skuratowicz, Architektura, p. 353 affirms that SYawski's pre-1914 designs were programmatically different from those of the Germans and this accounted for his popularity.

85. APP, Zarzạd Miejski m. Poznania, Wydzial Budownictwa, t. 86, pp. 7-8.

86. APP, Zarząd Miejski m. Poznania, Wydzial Budownictwa, t. 85, pp. 13-16.

87. Ignacy Kaczmarek, director of the third department at Poznańs municipal government. APP, Zarząd Miejski m. Poznania, Wydzial Budownictwa, t. 42, pp. 8-12.

88. See AAN, Urzạd Rady Ministrów, t. 5/492, pp. 1-32.

89. APP, Zarzạd Miejski m. Poznania, Wydzial Budownictwa, t. 86, p. 7.

90. APP, PDO, t. 54, p. 47.

91. On this issue, see Walter Bettenstaed, Das Rathaus in Posen und seine Herstellung in den Jahren 1910-13 (Posen: 1913).

92. See A. Möller van den Bruck, Der preußische Stil (Munich: Korn, 1953).

93. The same Sławski designed what could be called Prussian-style buildings. See Irma Kozina, Styl około 1800. Styl narodowy czy nowa rzeczywistość w architekturze Górnego Śląska? in Dariusz Konstantinow, Robert Pasieczni and Piotr Paszkiewicz, eds, Nacjonalizm, pp. 171-183, here p. 180.

94. All citations from APP, Zarząd Miejski m. Poznania, Wydzial Budownictwa, t. 86, pp. 1-3. Although the typical Prussian public facilities had no rendered walls-a consequence of the industrialized use of bricks - the difference between residential buildings of pre-partition times in Greater Poland and, for example, in the "German" neighboring region of Brandenburg was not great.

95. Report about the Old Town from 1946. "Stare Miasto Poznania. APP, Zarzạd Miejski m. Poznania, Wydzial Budownictwa, t. 86, pp. 20-23, here p. 23.

96. On the Piasts and their mythology, see Jerzy Strelczyk, Die Piasten. Tradition und Mythos in Polen, Adelheid von Saldern, ed., Mythen in Geschichte und Geschichtsschreibung aus polnischer und deutscher Sicht (Münster: Lit, 1996), pp. 113-131.

97. The alleged sarcophagus of the first Piasts, Mieszko I and Bolesław Chrobry, are preserved in the Golden Chapel of the cathedral. The construction of this monument was an early sign of Poznań's Polish nationalists. See Sven Ekdahl, Denkmal und Geschichts- 
ideologie im polnisch-preußischen Spannungsfeld, Historische Kommision zu Berlin, ed., Zum Verständnis der polnischen Frage in Preußen und Deutschland 1772- 1871 (Berlin: Colloquium, 1987), pp. 127-218.

98. See the article signed W.M.-possibly Witold Maisel, P.D.O.'s chief-Odbudowa katedry Poznańskiej, APP, PDO, t. 16, pp. 17-19.

99. Jerzy Ros, Poznańskie refleksje, Zycie Warszawy, 8 April 1948, p. 3.

100. On the cathedral, see Józef Nowacki, Kościól katedralny w Poznaniu. Studium historyczne (Poznań: Księgarnia Św. Wojciecha, 1959); and Jan Staniszlawski, ed., Piastowska Katedra w Poznaniu (Poznań: Księgarnia Św. Wojciecha, 1990).

101. Zalożenia ogólne dla odbudowy Starego Rynku w Poznaniu, APP, Miastoprojekt, t. 317a.

102. APP, Miastoprojekt, t. 317a.

103. See Kondziela, Stare Miasto, p. 68.

104. APP, Zarzạd Miejski m. Poznania, Wydzial Budownictwa, t. 92, pp. 1-19.

105. Ibid., p. 14.

106. Ibid., p. 13

107. APP, PDO, t. 16 , p. $1-4$, here p. 4.

108. APP, Zarzạd Miejski m. Poznania, Wydzial Budownictwa, t. 113, pp. 1-2.

109. See Kondziela and Jasiecka, Przeglạd zabytków, p. 20.

110. Important documents of the Town Curator and of the Pracownia Konserwacji Zabytków (Workshop of Conservation of Monuments) are allegedly not completely catalogued or at least not available.

111. The scheme approved by the expert commission in November 1945 did contain a Town Scale's plan; APP, Zarząd Miejski m. Poznania, Wydzial Budownictwa, t. 85. See also a 1946 report about the Old Town; APP, Zarząd Miejski m. Poznania, Wydzial Budownictwa, t. 86, pp. 20-23. However, Witold Maisel affirms that this idea of rebuilding the Town Scale was victorious only in 1956. See Witold Maisel, Ewolucja planów, p. 16.

112. See the folder on Waga Miejska in the Archiwum Konserwatora Zabytków miasta Poznania.

113. See, for example, Glos Wielkopolski, 23 October 1948, p. 3.

114. Poznań. Przewodnik, p. 81.

115. See APP, Zarząd Miejski m. Poznania, Wydzial Budownictwa, t. 113, pp. 1-2.. Drawings and blueprints in APP, Zarzạd Miejski m. Poznania, Wydzial Budownictwa, t. 114, pp. 8-10.

116. APP, Prezydium Miejskiej Rady Narodowej (Poznań), Wydzial ArchitektonicznoBudowlany, t. 146, pp. 22-26. Protocol of the session of the Town Commission of Urban Planners and Architects, 1956. The project was elaborated by Z. Zieliński and J. Cieslinski. There is no concrete description of such material.

117. See the investment plan of 23 September 1946. On other plans, APP, Zarząd Miejski m. Poznania, Wydzial Budownictwa, t. 113, pp. 1-2 (protocol of 25 February 1948). On actual use, see Glos Wielkopolski, 18-19 September 1960. The Western Institute is well known; today it is almost exclusively concerned with German studies.

118. Eugeniusz Linette, Studium historyczno-urbanistyczne. Poznań-Stare Miasto (Poznań: 1966), p. 31, typewritten copy. I found this study in the Archive of Greater Poland's Centre for Study and Defense of the Culture Environment (Wielkopolski Ośrodek Studiów i Ochrony Środowiska Kulturowego) in Poznan.

119. M. Christine Boyer, The City of Collective Memory. Its Historical Imagery and Architectural Entertainments (Cambridge, MA: MIT Press, 1994), p. 2.

120. See StanisIaw Latour, Rozwój architektury i urbanistyki na ziemiach zachodnich po II 
wojnie Swiatowej," in Polska Akademia Nauk, ed., Architektura i urbanistyka w Polsce (Warsaw: PWN, 1989), pp. 61-81.

121. "We live in a town where the past was reconstructed ... we move in the circle of a copied tradition and a controlled fantasy." Kazimierz Brandys's refined and ironic literary exposition of the problem in "Letters to Mrs. Z," in Listy do Pani Z (Warsaw: PIW, 1965), pp. 42-43.

122. After this article was completed, the frieze was covered up with enormous abstract pictures, reflecting another rewriting of history.

123. On Wroclaw, see Gregor Thum, Cleansed Memory; and Bollwerk Breslau. 